\title{
Editorial: AABFJ Volume 11, Issue 1, 2017
}

\author{
Gregory Jones $^{1}$, Claire Beattie ${ }^{2}$ and Afzalur Rashid ${ }^{3}$
}

The editors wish to firstly acknowledge to passing of Professor Michel Gaffikin. Professor Gaffikin's contribution to the world of accounting academia and particularly to the development of accounting theory cannot be overstated. His willingness to give of both his time and knowledge to the advancement of the accounting field is greatly appreciated. For much of his career he was employed by the University of Wollongong and was head of school for a number of years. In the latter part of his career he also worked as a mentor for academic staff at Western Sydney University. His generosity in providing support and guidance to accounting academics was influential to many emerging scholars. Through these efforts Professor Gaffikin has left his mark on the future of accounting research and education both in Australia and beyond. The quality of his own work has been both an inspiration and a constant delight. Michael's generosity of spirt and salient advice leave us with a lasting legacy that will continue to shape accounting academia. Michael's contribution has forever stamped his imprint on the future of both the profession and provides a reminder of how we should all conduct ourselves.

This issue of AABFJ begins with three papers exploring aspects of corporate governance. Rae, Sands and Subramaniam examines the associations between the five COSO and uses structural equation modelling to link these to good corporate governance. Their findings suggest that utilising the COSO internal control framework can lead to a better understanding of the direct, indirect and reciprocal associations among components of internal control systems. The following article by Uyar, Gungormus and Kuzey investigates the association between accounting information systems and corporate governance. The empirics suggest that corporate governance is positively impacted by bookkeeping, financial reporting and budgeting practices but that external monitoring devices such as the Turkish accounting and financial reporting standards are less effective in improving corporate governance. The final article on corporate governance explored the impact of corporate governance on the firm performance of listed companies on the Saudi Arabia stock exchange. In this study Buallay, Hamdan and Zureigat found that while corporate governance adoption does not affect firm financial performance; there was a significant impact from ownership and the size of the board of directors.

The final two papers in this issue consider research problems concerned with information asymmetry and consumer ethical decision making. Turki, Wali and Boujelbene link the mandatory adoption of IFRS/IAS in the European Union with the information content of

\footnotetext{
${ }^{1}$ University of Southern Queensland, Australia

${ }^{2}$ University of Southern Queensland, Australia

${ }^{3}$ University of Southern Queensland, Australia
} 
earnings. Their findings suggest that adoption of IFRS has been instrumental in reducing the cost of capital and the dispersion of financial analysts forecasts. This study provides evidence that IFRS adoption is effective in reducing information asymmetry. Finally, Shah and Amjad use a survey to demonstrate that self-consciousness mediates the relationship between moral intensity and neutralization. This is one of the first studies to link the issue contingent model, theory of neutralization and self-consciousness.

\section{References}

Buallay, Amina; Hamdan, Allam; and Zureigat, Qasim, Corporate Governance and Firm Performance: Evidence from Saudi Arabia, Australasian Accounting, Business and Finance Journal, 11(1), 2017, 78-98. doi:10.14453/aabfj.v11i1.6

Rae, Kirsten; Sands, John; and Subramaniam, Nava, Associations among the Five Components within COSO Internal Control-Integrated Framework as the Underpinning of Quality Corporate Governance, Australasian Accounting, Business and Finance Journal, 11(1), 2017, 28-54. doi:10.14453/aabfj.v11i1.4

Shah, Syed Afzal Moshadi and Amjad, Shehla, Consumer Ethical Decision Making: Linking Moral Intensity, Self-Consciousness and Neutralization Techniques, Australasian Accounting, Business and Finance Journal, 11(1), 2017, 99-130. doi:10.14453/aabfj.v11i1.7

Turki, Hela; Wali, Sonda; and Boujelbene, Younes, IFRS Mandatory Adoption Effect on the Information Asymmetry: Immediate or Delayed?,Australasian Accounting, Business and Finance Journal, 11(1), , 55-77. doi:10.14453/aabfj.v11i1.5

Uyar, Ali; Gungormus, Ali Haydar; and Kuzey, Cemil, Impact of the Accounting Information Systemon Corporate Governance: Evidence from Turkish Non-Listed Companies, Australasian Accounting,Business and Finance Journal, 11(1), 9-27. doi:10.14453/aabfj.v11i1.3 